\title{
Ureibacillus composti sp. nov. and Ureibacillus thermophilus sp. nov., isolated from livestock- manure composts
}

\author{
Hang-Yeon Weon, ${ }^{1}$ Seon-Young Lee, ${ }^{2}$ Byung-Yong Kim, ${ }^{2}$ \\ Hyung-Jun Noh, ${ }^{1}$ Peter Schumann, ${ }^{3}$ Jong-Shik Kim ${ }^{4}$ \\ and Soon-Wo Kwon ${ }^{2}$ \\ ${ }^{1}$ Applied Microbiology Division, National Institute of Agricultural Science and Technology, \\ Rural Development Administration (RDA), Suwon 441-707, Republic of Korea \\ ${ }^{2}$ Korean Agricultural Culture Collection (KACC), Microbial Genetics Division, National Institute of \\ Agricultural Biotechnology, Rural Development Administration (RDA), Suwon 441-707, \\ Republic of Korea \\ ${ }^{3} \mathrm{DSMZ}$ - Deutsche Sammlung von Mikroorganismen und Zellkulturen GmbH, Inhoffenstraße 7b, \\ 38124 Braunschweig, Germany \\ ${ }^{4}$ Department of Environmental Sciences, University of California, Riverside, CA 92521-0424, USA
}

Correspondence

Soon-Wo Kwon

swkwon@rda.go.kr

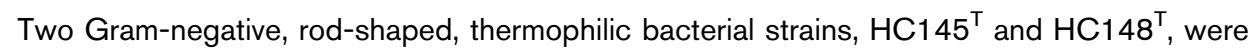
isolated from a compost sample from a compost facility in Ichon, Korea. Sequencing of the 16S rRNA genes of $\mathrm{HC} 145^{\top}$ and $\mathrm{HC}_{148}{ }^{\top}$ and comparative analyses of the resulting sequences clearly showed that these strains had a phylogenetic affiliation to the genus Ureibacillus. The level of $16 \mathrm{~S}$ rRNA similarity between the two novel strains was $98.4 \%$ and the levels of sequence

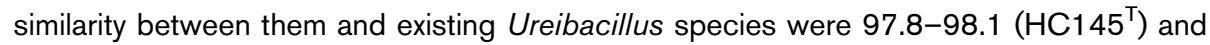
97.4-98.7\% $\left(\mathrm{HC}_{148}{ }^{\mathrm{T}}\right)$. The DNA-DNA reassociation values between the two strains and the type strains of Ureibacillus species ranged from 38 to $51 \%$. The polar lipid profiles for both isolates consisted of phosphatidylglycerol, diphosphatidylglycerol, phospholipids and glycolipids of unknown composition. The major quinones were MK-8, MK-9 and MK-7, the peptidoglycan type was L-Lys $\leftarrow D-A s p$ and the main cellular fatty acid was iso- $C_{16}: 0$. The DNA $G+C$ contents of strains $\mathrm{HC}_{145^{\top}}$ and $\mathrm{HC}_{148}{ }^{\top}$ were 42.4 and $38.5 \mathrm{~mol} \%$, respectively. On the basis of the data from this polyphasic study, strains $\mathrm{HC}_{145^{\top}}$ and $\mathrm{HC}_{148}{ }^{\top}$ represent members of the genus Ureibacillus, for which the names Ureibacillus composti sp. nov. and Ureibacillus thermophilus sp. nov., respectively, are proposed. The type strain of $U$. composti is $\mathrm{HC} 145^{\top}$ (=KACC $11361^{\top}$ $\left.=\mathrm{DSM} 17951^{\top}\right)$ and the type strain of $U$. thermophilus is $\mathrm{HC}_{148}{ }^{\top}\left(=\mathrm{KACC} 11362^{\top}=\mathrm{DSM}\right.$ $\left.17952^{\top}\right)$.
Members of Ureibacillus, a genus comprising thermophilic, aerobic, endospore-forming bacteria, have been isolated from air (Ureibacillus thermosphaericus; Andersson et al., 1995), soil (Ureibacillus terrenus; Fortina et al., 2001) and composts (Ureibacillus suwonensis; Kim et al., 2006). The temperature range for growth for members of this genus is 35-65 ${ }^{\circ} \mathrm{C}$, the optimum being $50-60{ }^{\circ} \mathrm{C}$ (Kim et al., 2006). Composting is a self-heating, aerobic, solid-phase, biodegradative process occurring in organic waste materials (de Bertoldi et al., 1983; Finstein \& Morris, 1975). During the thermogenic phase of the composting process, the

The GenBank/EMBL/DDBJ accession numbers for the 16S rRNA gene sequences of strain $\mathrm{HC} 145^{\top}$ and strain $\mathrm{HC}^{148^{\top}}$ are $\mathrm{DO} 348071$ and D0348072, respectively. temperature usually rises to $65-80{ }^{\circ} \mathrm{C}$ for a certain period of time. Thus, hot compost is considered to represent a favourable habitat for thermophilic strains. During the characterization of thermophilic bacteria isolated from livestock-manure composts, strains $\mathrm{HC}_{145^{\mathrm{T}}}$ and $\mathrm{HC}_{148}{ }^{\mathrm{T}}$ were recovered on trypticase soy agar at $\mathrm{pH} 7.0$ and incubated at $55{ }^{\circ} \mathrm{C}$. Strains $\mathrm{HC} 145^{\mathrm{T}}$ and $\mathrm{HC} 48^{\mathrm{T}}$ formed round, brown, convex colonies on both trypticase soy agar and nutrient agar (Oxoid). Gram staining was performed using a Difco Gram-stain kit according to the manufacturer's recommended protocol. A $\mathrm{KOH}$ test and an Lalanine aminopeptidase assay were also performed (Gregersen, 1978). Cell morphology was observed under a phase-contrast microscope after 2 days incubation on CASO agar (DSMZ medium no. 220; http://www.dsmz.de/ 
media/media.htm) supplemented with $\mathrm{MnSO}_{4}$ at 10$100 \mathrm{mg} \mathrm{l}^{-1}$. The Voges-Proskauer test and tests for the following physiological traits were carried out according to Gordon et al. (1973) and Claus \& Berkeley (1986): catalase, anaerobic growth, temperature range for growth (30$70{ }^{\circ} \mathrm{C}$, in increments of $5{ }^{\circ} \mathrm{C}$ ), growth in the presence of $\mathrm{NaCl}(0,2,5,7$ and $10 \%, \mathrm{w} / \mathrm{v})$, growth at $\mathrm{pH} 4-10$, acids from carbohydrates (D-glucose, L-arabinose, D-xylose and D-mannitol), formation of gas from glucose, hydrolysis of starch, nitrate reduction, production of indole, deamination of phenylalanine, decomposition of casein and tyrosine and liquefaction of gelatin. The oxidase test and the determination of aesculin hydrolysis were conducted according to Smibert \& Krieg (1994). Motility tests were performed on 1/10-strength CESP agar (1.5 g Casitone, $0.5 \mathrm{~g}$ yeast extract, $0.3 \mathrm{~g}$ soytone, $0.2 \mathrm{~g}$ peptone, $0.015 \mathrm{~g}$ $\mathrm{MgSO}_{4}, 0.007 \mathrm{~g} \mathrm{FeCl}_{2}$ and $0.002 \mathrm{~g} \mathrm{MnCl}_{2}$, made up to $1 \mathrm{l}$ with distilled water; pH 7.2) (Fortina et al., 2001). Strain
$\mathrm{HC} 148^{\mathrm{T}}$ did not form spores on CASO agar medium supplemented with $\mathrm{MnSO}_{4}$ at $10-100 \mathrm{mg} \mathrm{l}^{-1}$, unlike other strains within the genus Ureibacillus. The physiological and biochemical properties of strains $\mathrm{HC} 145^{\mathrm{T}}$ and $\mathrm{HC} 148^{\mathrm{T}}$ and the three existing species within the genus Ureibacillus are shown in Table 1.

The 16S rRNA gene sequences were determined by using PCR amplification (Kwon et al., 2003). The sequences were aligned together with those of the type strains of the genus Ureibacillus by using the CLUSTAL $\mathrm{w}$ program (Thompson et al., 1994). The evolutionary tree for the dataset was inferred with the neighbour-joining and maximum-parsimony methods, using MEGA 3.1 (Kumar et al., 2004). The stability of relationships was assessed by performing bootstrap analyses based on 1000 resamplings. Phylogenetic analyses based on 16S rRNA gene sequences confirmed that strains $\mathrm{HC} 145^{\mathrm{T}}$ and $\mathrm{HC} 148^{\mathrm{T}}$ are members

\section{Table 1. Phenotypic characteristics of Ureibacillus species}

Taxa: 1, strain $\mathrm{HC}_{145^{\mathrm{T}}} ; 2$, strain $\mathrm{HC}_{148}^{\mathrm{T}} ; 3$, U. thermosphaericus (unless indicated, data from Fortina et al., 2001); 4, U. terrenus (Fortina et al., 2001); 5, U. suwonensis (Kim et al., 2006). For the fatty acid analyses carried out in this study, cells for all strains were harvested after growth on R2A agar at $50{ }^{\circ} \mathrm{C}$ for 2 days. All strains were positive for catalase, oxidase and the deamination of phenylalanine. All strains gave negative results in the $\mathrm{KOH}$ assay, the L-alanine aminopeptidase assay and for the hydrolysis of casein, gelatin, starch and urease. +, Positive; -, negative or not detected (or $<1 \%$ in fatty acid compositions); v, variable; ND, not determined.

\begin{tabular}{|c|c|c|c|c|c|}
\hline Characteristic & 1 & 2 & 3 & 4 & 5 \\
\hline Spore shape ${ }^{\star}$ & S & $\mathrm{ND}$ & S & S & s/o \\
\hline $35^{\circ} \mathrm{C}$ & - & + & - & - & + \\
\hline $65^{\circ} \mathrm{C}$ & - & + & - & + & - \\
\hline $5 \% \mathrm{NaCl}$ & + & + & + & $\mathrm{V}$ & + \\
\hline Aesculin & + & + & + & + & - \\
\hline Tyrosine & - & + & - & + & - \\
\hline \multicolumn{6}{|l|}{ Fatty acids (\%): $\dagger$} \\
\hline iso- $\mathrm{C}_{14: 0}$ & 1.5 & 2.0 & 4.7 & - & - \\
\hline iso- $\mathrm{C}_{15: 0}$ & 2.9 & 4.0 & 10.2 & 1.4 & - \\
\hline anteiso- $\mathrm{C}_{15: 0}$ & - & 1.1 & - & - & - \\
\hline $\mathrm{C}_{17: 0}$ & - & 1.8 & - & 2.1 & - \\
\hline iso- $\mathrm{C}_{17: 0}$ & 2.3 & 5.9 & 2.5 & 5.5 & 1.2 \\
\hline anteiso- $\mathrm{C}_{17: 0}$ & 2.7 & 6.8 & - & 3.4 & - \\
\hline iso- $\mathrm{C}_{18: 0}$ & 1.0 & 1.0 & - & 2.7 & 1.0 \\
\hline Summed feature $4 \ddagger$ & - & 2.6 & - & - & - \\
\hline Major menaquinone(s) (\%) & $\begin{array}{l}\text { MK-7, MK-8, MK-9, } \\
\text { MK-10 }(50: 40: 10: 1)\end{array}$ & $\begin{array}{l}\text { MK-8, MK-9, MK-7, } \\
\text { MK-10 (43:35:21:2) }\end{array}$ & MK-7 $(>90)$ & $\begin{array}{c}\text { MK-9, MK-8, MK- } \\
\text { 10, MK-7, MK-11 } \\
(58: 22: 14: 1: 1)\end{array}$ & $\begin{array}{c}\text { MK-9, MK-8, MK-7, } \\
\text { MK-10, MK-6 } \\
(45: 27: 18: 5: 4)\end{array}$ \\
\hline DNA $\mathrm{G}+\mathrm{C}$ content $(\mathrm{mol} \%)$ & 42.4 & 38.5 & $35.7-39.2$ & $39.6-41.5$ & 41.5 \\
\hline
\end{tabular}

${ }^{*}$ S, Spherical; o, oval.

$\dagger$ Data were obtained from this study, using type strains of Ureibacillus species.

\$Comprises iso- $\mathrm{C}_{17: 1} \mathrm{I}$ and/or anteiso- $\mathrm{C}_{17: 1} \mathrm{~B}$. 
of the genus Ureibacillus (Fig. 1). The level of 16S rRNA gene sequence similarity between strains $\mathrm{HC} 145^{\mathrm{T}}$ and $\mathrm{HC}_{148}{ }^{\mathrm{T}}$ was $98.4 \%$ and the levels of similarity between strains $\mathrm{HC} 145^{\mathrm{T}}$ and $\mathrm{HC} 148^{\mathrm{T}}$ and the type strains of other Ureibacillus species were in the ranges $97.8-98.1 \%$ and 97.4-98.7\%, respectively. Strains $\mathrm{HC}_{145^{\mathrm{T}}}$ and $\mathrm{HC}_{148}{ }^{\mathrm{T}}$ and the type strains of the three existing species within the genus Ureibacillus were clustered into one clade with a high level of bootstrap support (100\%). This was also supported by the tree constructed using the maximum-parsimony method.

DNA-DNA hybridization was carried out by using the filter hybridization method described by Seldin \& Dubnau (1985). Probe labelling was conducted using the nonradioactive DIG-High Prime system (Roche) and DNADNA relatedness was quantified using a densitometer (Bio-Rad). The DNA relatedness between strains $\mathrm{HC} 145^{\mathrm{T}}$ and $\mathrm{HC} 148^{\mathrm{T}}$ was $42 \%$. Strains $\mathrm{HC}{ }^{\mathrm{T}}$ and $\mathrm{HC} 148^{\mathrm{T}}$ exhibited only $42-51$ and $38-45 \%$ relatedness, respectively, to the type strains of the three recognized species.

DNA G + C contents were determined by means of HPLC analysis of deoxyribonucleosides, as described by Mesbah et al. (1989), using a reversed-phase column (Supelcosil LC-18 S; Supelco). The preparation of cell walls and the determination of peptidoglycan structure was carried out at the DSMZ as described by Schleifer (1985) and Schleifer \& Kandler (1972) except that TLC on cellulose was used instead of paper chromatography. Polar lipid analyses were carried out by the Identification Service of the DSMZ (Tindall, 1990). After growth of the cells on R2A for 2 days at $50{ }^{\circ} \mathrm{C}$, fatty acid methyl esters were extracted and prepared using the standard protocol of the Microbial Identification system (MIDI; Microbial ID). The DNA $\mathrm{G}+\mathrm{C}$ content of strain $\mathrm{HC} 148^{\mathrm{T}}$ was $38.5 \mathrm{~mol} \%$, which lies within the range observed for members of the genus Ureibacillus, while the content of $\mathrm{HC} 145^{\mathrm{T}}$ was $42.4 \mathrm{~mol} \%$, which is a little higher than those reported previously for Ureibacillus type strains (35.7-41.5 mol\%). Fatty acid profiles for members of the genus Ureibacillus (Table 1) revealed that all of the strains contained iso- $\mathrm{C}_{16: 0}$ as the

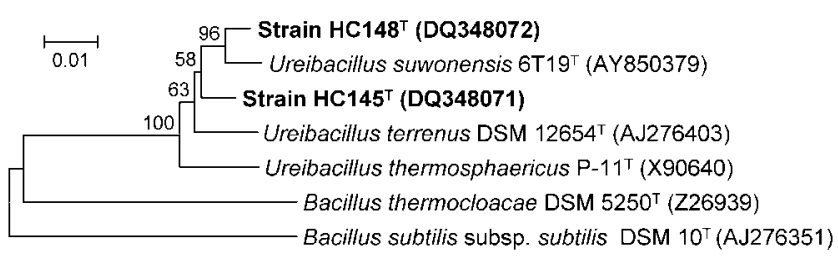

Fig. 1. Neighbour-joining phylogenetic tree, based on $16 \mathrm{~S}$ rRNA gene sequences, showing the positions of $\mathrm{HC}_{145^{\top}}$ and $\mathrm{HC} 148^{\top}$ and closely related species. Numbers at nodes indicate percentages of bootstrap support, based on a neighbour-joining analysis of 1000 resampled datasets. Bootstrap values below $50 \%$ are not indicated. Bar, 0.01 substitutions per nucleotide position. predominant fatty acid (60.0-77.3\%). The minor fatty acid compositions among the strains were found to be very variable. Strain $\mathrm{HC}_{148}{ }^{\mathrm{T}}$ was unique in containing summed feature 4 (iso- $\mathrm{C}_{17: 1} \mathrm{I}$ and/or anteiso- $\mathrm{C}_{17: 1} \mathrm{~B} ; 2.6 \%$ ). The peptidoglycan cross-linkage in the two novel strains was of the L-Lys $\leftarrow D$-Asp type (variation A4 $\alpha$ ). The polar lipids consisted of phosphatidylglycerol, diphosphatidylglycerol, phospholipids and glycolipids of unknown composition. These results were in accordance with those given in the description of the genus Ureibacillus (Fortina et al., 2001).

Phenotypic features that serve to distinguish strains $\mathrm{HC}_{145^{\mathrm{T}}}$ and $\mathrm{HC} 148^{\mathrm{T}}$ from recognized Ureibacillus species are shown in Table 1. Strains $\mathrm{HC} 145^{\mathrm{T}}$ and $\mathrm{HC} 148^{\mathrm{T}}$ could be differentiated from each other on the basis of the following features: temperature range for growth, tyrosine hydrolysis and DNA G $+\mathrm{C}$ content. The two novel strains can be distinguished from recognized Ureibacillus strains on the basis of several phenotypic properties as well as some chemotaxonomic properties such as fatty acid composition and menaquinone content (Table 1). Furthermore, the DNA-DNA reassociation values (below $70 \%$ ) and the $16 \mathrm{~S}$ rRNA gene sequence analysis confirmed the distinct positions of strains $\mathrm{HC} 145^{\mathrm{T}}$ and $\mathrm{HC} 148^{\mathrm{T}}$ within the genus Ureibacillus.

On the basis of the data from this polyphasic taxonomic study, strains $\mathrm{HC} 145^{\mathrm{T}}$ and $\mathrm{HC} 148^{\mathrm{T}}$ represent two novel species of the genus Ureibacillus, for which we propose the names Ureibacillus composti sp. nov. and Ureibacillus thermophilus sp. nov., respectively.

\section{Description of Ureibacillus composti sp. nov.}

Ureibacillus composti (com.pos'ti. N.L. gen. n. composti of compost).

Cells are Gram-negative, motile, rod-shaped bacteria, 0.7$0.9 \mu \mathrm{m}$ wide and $2.5-4.0 \mu \mathrm{m}$ long. They bear spherical endospores that lie in subterminal or terminal positions. Round, light-brown, convex colonies are formed. Grows at $37-60{ }^{\circ} \mathrm{C}$ and $\mathrm{pH} 6-8$. Tolerates up to $5 \% \mathrm{NaCl}(\mathrm{w} / \mathrm{v})$. Aesculin is hydrolysed. Casein, gelatin, tyrosine, starch and urea are not hydrolysed. Positive for catalase, oxidase and deamination of phenylalanine. Negative for anaerobic growth, glucose fermentation, indole formation, nitrate reduction, acid production from D-glucose, L-arabinose, Dxylose and D-mannitol and in the Voges-Proskauer test. Peptidoglycan cross-linkage is of the L-Lys $\leftarrow D$-Asp type (variation $\mathrm{A} 4 \alpha$ ). The major cellular fatty acid is iso- $\mathrm{C}_{16: 0}$. The major quinones are MK-7, MK-8 and MK-9. Polar lipids consist of phosphatidylglycerol, diphosphatidylglycerol, phospholipids and glycolipids of unknown composition. The DNA G+C content of the type strain is $42.4 \mathrm{~mol} \%$.

The type strain, $\mathrm{HC}_{145^{\mathrm{T}}}\left(=\mathrm{KACC} 11361^{\mathrm{T}}=\mathrm{DSM} 17951^{\mathrm{T}}\right)$, was isolated from livestock-manure compost from Ichon, Korea. 


\section{Description of Ureibacillus thermophilus sp. nov.}

Ureibacillus thermophilus (ther.mo' phi.lus. Gr. adj. thermos hot; Gr. adj. philos loving; N.L. masc. adj. thermophilus heat-loving).

Cells are Gram-negative, motile, rod-shaped bacteria, 0.8$1.2 \mu \mathrm{m}$ wide and $2.5-3.5 \mu \mathrm{m}$ long. Round, light-brown, convex colonies are formed. Grows at $30-65{ }^{\circ} \mathrm{C}$ and $\mathrm{pH} 6-$ 8. Tolerates up to $5 \% \mathrm{NaCl}(\mathrm{w} / \mathrm{v})$. Aesculin and tyrosine are hydrolysed. Casein, gelatin, starch and urea are not hydrolysed. Positive for catalase, oxidase and deamination of phenylalanine. Negative for anaerobic growth, glucose fermentation, indole formation, nitrate reduction, acid production from D-glucose, L-arabinose, D-xylose and Dmannitol and in the Voges-Proskauer test. Peptidoglycan cross-linkage is of the L-Lys $\leftarrow \mathrm{D}$-Asp type (variation A4 $\alpha$ ). The major cellular fatty acid is iso- $\mathrm{C}_{16: 0}$. The major quinones are MK-8, MK-9 and MK-7. Polar lipids consist of phosphatidylglycerol, diphosphatidylglycerol, phospholipids and glycolipids of unknown composition. The DNA $\mathrm{G}+\mathrm{C}$ content of the type strain is $38.5 \mathrm{~mol} \%$.

The type strain, $\mathrm{HC}_{148}{ }^{\mathrm{T}}\left(\right.$ KACC $\left.11362^{\mathrm{T}}=\mathrm{DSM} 17952^{\mathrm{T}}\right)$, was isolated from livestock-manure compost from Ichon, Korea.

\section{Acknowledgements}

This study was supported by a programme of international collaborative research (NIAB grant no. 06-4-11-19-3) between the Rural Development Administration (Suwon, Republic of Korea) and the Deutsche Sammlung von Mikroorganismen und Zellkulturen (Braunschweig, Germany).

\section{References}

Andersson, M., Laukkanen, M., Nurmiaho-Lassila, E.-L., Rainey, F. A., Niemela, S. I. \& Salkinoja-Salonen, M. (1995). Bacillus thermosphaericus sp. nov.: a new thermophilic ureolytic bacillus isolated from air. Syst Appl Microbiol 18, 203-220.

Claus, D. \& Berkeley, R. C. W. (1986). Genus Bacillus Cohn 1872. In Bergey's Manual of Systematic Bacteriology, vol. 2, pp. 1105-1140. Edited by P. H. A. Sneath, N. S. Mair, M. E. Sharpe \& J. G. Holt. Baltimore: Williams \& Wilkins. de Bertoldi, M., Vallini, G. \& Pera, A. (1983). The biology of composting, a review. Waste Manag Res 1, 157-176.

Finstein, M. S. \& Morris, M. L. (1975). Microbiology of municipal solid waste composting. Adv Appl Microbiol 19, 113-151.

Fortina, M. G., Pukall, R., Schumann, P., Mora, D., Parini, C., Manachini, P. L. \& Stackebrandt, E. (2001). Ureibacillus gen. nov., a new genus to accommodate Bacillus thermosphaericus (Anderson et al. 1995), emendation of Ureibacillus thermosphaericus and description of Ureibacillus terrenus sp. nov. Int J Syst Evol Microbiol 51, 447-455.

Gordon, R. E., Haynes, W. C. \& Pang, C. H.-N. (1973). The Genus Bacillus. US Department of Agriculture Handbook no. 427. Washington, DC: Agricultural Research Service.

Gregersen, T. (1978). Rapid method for distinction of Gram-negative from Gram-positive bacteria. Eur J Appl Microbiol Biotechnol 5, 123-127.

Kim, B.-Y., Lee, S.-Y., Weon, H.-Y., Kwon, S.-W., Go, S.-J., Park, Y.-K., Schumann, P. \& Fritze, D. (2006). Ureibacillus suwonensis sp. nov. isolated from cotton waste composts. Int J Syst Evol Microbiol 56, 663-666.

Kumar, S., Tamura, K. \& Nei, M. (2004). MEGA3: integrated software for molecular evolutionary genetics analysis and sequence alignment. Brief Bioinform 5, 150-163.

Kwon, S. W., Kim, J. S., Park, I. C., Yoon, S. H., Park, D. H., Lim, C. K. \& Go, S. J. (2003). Pseudomonas koreensis sp. nov., Pseudomonas umsongensis sp. nov. and Pseudomonas jinjuensis sp. nov., novel species from farm soils in Korea. Int J Syst Evol Microbiol 53, 21-27.

Mesbah, M., Premachandran, U. \& Whitman, W. B. (1989). Precise measurement of the $\mathrm{G}+\mathrm{C}$ content of deoxyribonucleic acid by highperformance liquid chromatography. Int J Syst Bacteriol 39, 159-167.

Schleifer, K. H. (1985). Analysis of the chemical composition and primary structure of murein. Methods Microbiol 18, 123-156.

Schleifer, K. H. \& Kandler, O. (1972). Peptidoglycan types of bacterial cell walls and their taxonomic implications. Bacteriol Rev 36, 407-477.

Seldin, L. \& Dubnau, D. (1985). Deoxyribonucleic acid homology among Bacillus polymyxa, Bacillus macerans, Bacillus azotofixans, and other nitrogen-fixing Bacillus strains. Int J Syst Bacteriol 35, 151-154.

Smibert, R. M. \& Krieg, N. R. (1994). Phenotypic characterization. In Methods for General and Molecular Bacteriology, pp. 607-654. Edited by P. Gerhardt, R. G. E. Murray, W. A. Wood \& N. R. Krieg. Washington, DC: American Society for Microbiology.

Thompson, J. D., Higgins, D. G. \& Gibson, T. J. (1994). CLUSTAL W: improving the sensitivity of progressive multiple sequence alignment through sequence weighting, position-specific gap penalties and weight matrix choice. Nucleic Acids Res 22, 4673-4680.

Tindall, B. J. (1990). Lipid composition of Halobacterium lacusprofundi. FEMS Microbiol Lett 66, 199-202. 